\title{
Model Pembelajaran Sq3r (Survey, Question, Read, Recite, Review) dengan Media Audio Visual Guna Meningkatkan Prestasi Belajar Bahasa Indonesia
}

\author{
Ni Made Sidri ${ }^{1}$ \\ 1SMP Negeri 2 Blahbatuh \\ Gianyar, Indonesia \\ email: madesidri65@gmail.com
}

\begin{abstract}
Abstrak
Penelitian ini dilaksanakan di SMP kelas IX H yang kemampuan siswanya untuk mata pelajaran Bahasa Indonesia masih sangat rendah. Tujuan penulisan penelitian tindakan kelas ini adalah untuk meningkatkan prestasi belajar Bahasa Indonesia siswa kelas IX H pada semester II tahun pelajaran 2018/2019 melalui penerapan model pembelajaran SQ3R (Survey, Question, Read, Recite, Review) dengan media audio visual. Metode pengumpulan datanya adalah observasi dan tes prestasi belajar. Metode analisis datanya adalah deskriptif. Dengan hasil yang diperoleh dari penelitian ini adalah model pembelajaran yang diterapkan dapat meningkatkan prestasi belajar siswa. Ini terbukti dari hasil yang diperoleh pada awalnya hanya mencapai rata-rata 67,35 dan ketuntasan belajar $35,29 \%$, pada siklus I meningkat menjadi 74,70 dengan ketuntasan belajar $61,76 \%$ dan pada Siklus II meningkat menjadi 81,61 dengan ketuntasan belajar mencapai $100 \%$. Kesimpulan yang diperoleh dari penelitian ini adalah penerapan model pembelajaran SQ3R (Survey, Question, Read, Recite, Review) dengan media audio visual dapat meningkatkan prestasi belajar Bahasa Indonesia siswa kelas IX H SMP pada semester II tahun pelajaran 2018/2019.
\end{abstract}

Kata Kunci: Model Pembelajaran SQ3R (Survey, Question, Read, Recite, Review), Media Audio visual, Prestasi Belajar.

\begin{abstract}
This research was conducted at SMP in class IX H, where the students' ability in Indonesian is still very low. The purpose of writing this classroom action research is to improve the learning achievement of Indonesian class IX H students in the second semester of the 2018/2019 academic year through the application of the SQ3R learning model (Survey, Question, Read, Recite, Review) with audio-visual media. The data collection methods are observation and learning achievement tests. The data analysis method is descriptive. With the results obtained from this study is the learning model that is applied to improve student achievement. This is evident from the results obtained at first only reaching an average of 67.35 and completeness of learning $35.29 \%$, in cycle I increased to 74.70 with completeness of learning $61.76 \%$ and in cycle II increased to 81.61 with completeness learn up to $100 \%$. The conclusion obtained from this research is that the application of the SQ3R (Survey, Question, Read, Recite, Review) learning model with audio-visual media can improve the Indonesian language learning achievement of class IX H students in the second semester of the 2018/2019 academic year.
\end{abstract}

Keywords: SQ3R Learning Model (Survey, Question, Read, Recite, Review), Audio-visual Media, Learning Achievement.

\section{Pendahuluan}

Undang-undang Sistem Pendidikan Nasional No. 20 tahun 2003 pasal 1 ayat 1 disebutkan bahwa pendidikan adalah usaha sadar dan terencana untuk mewujudkan suasana belajar dan proses pembelajaran agar siswa secara aktif mengembangkan potensi dirinya

\footnotetext{
*Corresponding author.

Received 03 Februari 2020; Accepted 31 July 2020; Available online 1 September 2020 (c) 2020 MPI. All Rights Reserved
} 
untuk memiliki kekuatan spiritual keagamaan, pengendalian diri, kepribadian, kecerdasan, akhlak mulia, serta keterampilan yang diperlukan dirinya, masyarakat, bangsa, dan negara.

Menurut Aunurrahman, (2009: 176) keberhasilan proses pembelajaran merupakan muara dari seluruh aktivitas yang dilakukan guru dan siswa, artinya apapun bentuk kegiatankegiatan guru mulai dari merancang pembelajaran, memilih dan menentukan materi, pendekatan, strategi dan metode pembelajaran, memilih dan menggunakan teknik evaluasi semua disarankan untuk mencapai keberhasilan belajar siswa.

Sanjaya (2006) sehubungan dengan pelaksanaan pembelajaran yang berlangsung selama ini menyatakan, bahwa "salah satu permasalahan yang muncul dalam dunia pendidikan adalah lemahnya proses pembelajaran. Pembelajaran cenderung verbalistik yaitu anak diarahkan untuk menghafal setiap informasi dan kurang diarahkan untuk memahami informasi yang diberikan oleh seorang guru. Oleh karena itu, diperlukan bentuk/model pembelajaran yang kritis. Seorang anak tentunya tidak bisa berpikir kritis dan mengembangkan setiap kemampuannya, karena strategi pembelajaran berfikir tidak digunakann dengan baik dalam proses pembelajaran."

Keberhasilan proses pembelajaran lebih banyak ditentukan oleh kemampuan guru dalam mengelola proses pembelajaran tersebut. Kadang ada guru yang disebut pintar tetapi lemah dalam menyampaikan pengetahuan dan pemahaman yang ada dalam dirinya maka tentu proses pembelajaran tidak akan berhasil dengan baik. Kadang ada guru yang disebut tidak terlalu pintar tetapi dalam menyampaikan dan mengelola pembelajaran lebih kreatif dan memahami cara penyampaiannya bisa jadi menyebabkan proses pembelajaran akan berhasil dengan baik. Di antara keduanya tentu yang paling sesuai adalah memiliki kemampuan profesionalisme keguruan dan mampu menyampaikan dengan baik demi terciptanya proses dan tujuan pembelajaran yang diharapkan untuk mampu meningkatkan ketakwaan terhadap Tuhan Yang Maha Esa.

Sehubungan dengan proses pembelajaran yang berlangsung di SMP Negeri 2 Blahbatuh dari hasil pengumpulan data awal didapat nilai rata-rata siswa kelas IX H pada mata pelajaran Bahasa Indonesia baru mencapai 67,35 dengan ketuntasan belajar hanya mencapai $35,29 \%$. Hasil tersebut tentu tidak sesuai dengan harapan keberhasilan pendidikan yang ditetapkan yaitu 75,00.

Berdasarkan observasi yang telah dilakukan, terlihat bahwa siswa kurang antusias dalam mengikuti pembelajaran yang dilakukan oleh guru. Hal itu dikarenakan guru cenderung monoton dalam melaksanakan proses pembelajaran. Selain itu, pembelajaran lebih didominasi dengan ceramah. Hal ini menyebabkan siswa menjadi jenuh dalam mengikuti pembelajaran Bahasa Indonesia di kelas.

Untuk mengatasi permasalahan di atas, perlu adanya upaya perbaikan dalam proses pembelajaran agar dapat meningkatkan keterampilan proses dalam pembelajaran Bahasa Indonesia. Salah satu alternatif yang digunakan yaitu dengan menggunakan model pembelajaran SQ3R (Survey, Question, Read, Recite, Review) dengan media audio visual.

Dengan penerapan model pembelajaran SQ3R (Survey, Question, Read, Recite, Review) dengan media audio visual diharapkan kemampuan analisis siswa dapat meningkat. Pembelajaran berbasis masalah tidak bisa terlepas dari metode pemecahan masalah, hal ini karena pembelajaran masalah berakar dari metode pemecahan masalah. Metode pemecahan masalah merupakan salah satu cara penyajian bahan pelajaran yang menjadikan masalah sebagai titik tolak pembahasan untuk dianalisis dan disintesis untuk menemukan jawaban.

\section{Metode Penelitian}

Penelitian ini dilaksanakan di SMP Negeri 2 Blahbatuh. Jadwal pelaksanaaan penelitian ini adalah pada semester II tahun pelajaran 2018/2019 (antara bulan Januari s.d Juni 2019).

Pada penelitian ini, peneliti memilih rancangan yang sesuai dengan penelitian yang dilakukan yaitu penelitian tindakan kelas (PTK). Penelitian tindakan kelas ini dilakukan agar dapat memecahkan suatu masalah yang dialami oleh seorang guru ketika mengajar di kelas. Dalam penelitian tindakan kelas (PTK) ini mengacu pada teori yang dikemukakan Kemmis dan 
Taggrat (dalam Agung, 2014: 140). Model penelitian ini terdapat empat tahapan pada satu siklus penelitian empat tahapan tersebut sesuai dengan yang telah dijelaskan di atas. Siklus ini dapat digambarkan sebagai berikut.

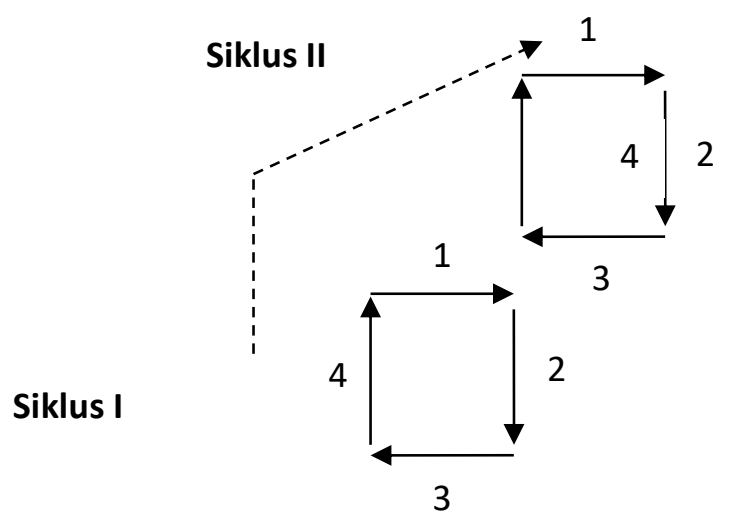

Keterangan:

Gambar 1. Model PTK Dua Siklus (Agung, 2014: 141)

1. Tahap perencanaan

2. Tahap tindakan

3. Tahap observasi/evaluasi

4. Tahap refleksi

\section{Siklus I}

Berdasarkan bagan, tahapan kegiatan penelitian dapat dijelaskan sebagai berikut:

\section{Perencanaan Tindakan}

Adapun perencanaan yang dilakukan untuk melaksanankan penelitian tindakan kelas adalah sebagai berikut.

1) Berkoordinasi dengan kepala sekolah untuk melaksanakan penelitian

2) Melakukan refleksi awal dengan melihat prestasi belajar Bahasa Indonesia siswa sebelum dilaksanakan penelitian.

3) Melakukan analisis kurikulum untuk mengetahui standar kompetensi, kompetensi dasar dan menyusun silabus yang disampaikan kepada siswa dengan menggunakan model pembelajaran SQ3R (Survey, Question, Read, Recite, Review) dengan media audio visual.

4) Menyusun Rencana Pelaksanaan Pembelajaran (RPP) dilengkapi LKS yang dirancang. Langkah-langkah pembelajarannya diarahkan pada model pembelajaran SQ3R (Survey, Question, Read, Recite, Review) dengan media audio visual untuk materi yang diajarkan.

5) Menyusun lembar penilaian dan tes/evaluasi berupa tes prestasi belajar dan kuesioner motivasi belajar.

6) Membuat ringkasan materi yang dibahas.

7) Membuat instrumen untuk penelitian tindakan kelas berupa lembar refleksi.

\section{Pelaksanaan Tindakan}

Dalam pelaksanaan ini disusun sesuai dengan tahap pelaksanaan penerapan model pembelajaran SQ3R (Survey, Question, Read, Recite, Review) dengan media audio visual dalam mata pelajaran Bahasa Indonesia untuk mengetahui prestasi belajar siswa. Pada setiap siklus penelitian terdiri dari 4 kali pertemuan. 3 kali pertemuan untuk melaksanakan proses pembelajaran dan 1 kali pertemuan untuk melaksanakan evaluasi atau tes prestasi belajar dan mengukur motivasi belajar siswa. Langkah-langkahnya adalah sebagai berikut.

1) Persiapan pada awal pembelajaran 
Pada tahap ini, kegiatan yang dilaksanakan adalah mempersiapkan perangkat pembelajaran, membentuk kelompok learning komunity, menetukan skor awal, mengatur tempat duduk dan melakukan kegiatan apersepsi.

2) Pelaksanaan pembelajaran

Langkah-langkah dalam pelaksanaan tindakan ini adalah dilaksanakan sesuai dengan Rencana Pelaksanaan Pembelajaran (RPP) yang telah disusun dan disiapkan dengan menerapkan tahap-tahap model pembelajaran SQ3R (Survey, Question, Read, Recite, Review) dengan media audio visual.

3. Observasi / Evaluasi

Pada pertemuan ke 4, guru melaksanakan tes prestasi belajar dan mengukur motivasi belajar siswa. Kegiatan yang dilakukan pada tahap evaluasi yaitu memberikan lembar tes evaluasi kepada siswa yang bertujuan untuk mengetahui prestasi belajar siswa dan kuesioner motivasi belajar untuk mengetahui tingkat motivasi belajar siswa setelah dilaksanakannya pembelajaran dengan model pembelajaran SQ3R (Survey, Question, Read, Recite, Review) dengan media audio visual. Hasil evaluasi akan menjadi acuan bagi peneliti dalam merancang pembelajaran pada siklus berikutnya (siklus II).

4. Refleksi

Refleksi ini dilakukan untuk melihat dan mengkaji hasil tindakan pada siklus I mengenai prestasi belajar Bahasa Indonesia dan motivasi belajar siswa. Hasil kajian tindakan siklus I ini, selanjutnya dipikirkan untuk dicari dan ditetapkan beberapa alternatif tindakan baru yang diduga lebih efektif untuk meningkatkan prestasi belajar Bahasa Indonesia. Alternatif tindakan ini ditetapkan menjadi tindakan baru pada rencana tidakan dalam penelitian.

Setelah data dalam penelitian ini terkumpul maka selanjutnya dilakukan analisis data. Analisis data ini menggunakan metode analisis statistik deskriptif kuantitatif. Agung (2011:61) menyatakan bahwa: "metode analisis deskriptif kuantitatif adalah suatu cara pengolahan data yang dilakukan dengan jalan menyusun secara sistematis dalam bentuk angka-angka atau persentase mengenai keadaan suatu objek yang diteliti sehingga diperoleh kesimpulan umum". Indikator keberhasilan penelitian yang diusulkan dalam penelitian ini pada siklus I dan siklus II mencapai nilai rata-rata minimal 75,00 dengan ketuntasan belajar minimal $85 \%$.

\section{Hasil Dan Pembahasan}

Model pembelajaran SQ3R (Survey, Question, Read, Recite, Review) dengan media audio visual merupakan metode yang bersifat praktis dan bisa diaplikasikan dalam berbagai pendekatan belajar. Model pembelajaran SQ3R pada prinsipnya merupakan singkatan dari langkah-langkah mempelajari teks, yang meliputi: Pertama, Survey yakni memeriksa atau meneliti atau mengidentifikasi seluruh teks. Kedua, Question, yakni menyusun daftar pertanyaan yang relevan dengan teks. Ketiga, Read, yakni membaca teks secara aktif untuk mencari jawaban atas pertanyaan-pertanyaan yang telah tersusun. Keempat, Recite, yakni menghafal setiap jawaban yang telah ditemukan. Kelima, Review, yakni meninjau ulang seluruh jawaban atas pertanyaan yang tersusun pada langkah ke dua dan ketiga.

Berdasarkan data awal yang diperoleh dengan rata-rata 67,35 dengan ketuntasan belajar hanya mencapai 35,29\% menunjukkan bahwa kemampuan anak/siswa dalam mata pelajaran Bahasa Indonesia masih sangat rendah mengingat kriteria ketuntasan belajar siswa untuk mata pelajaran ini di SMP Negeri 2 Blahbatuh adalah 75,00. Hal ini dikarenakan metode yang digunakan masih bersifat konvensional, dan guru hanya berceramah dalam menyampaikan materi sehingga siswa kesulitan dalam menerima pelajaran. Dengan nilai yang sangat rendah seperti itu maka peneliti mengupayakan untuk dapat meningkatkan prestasi belajar siswa menggunakan model SQ3R (Survey, Question, Read, Recite, Review) dengan media audio visual. Akhirnya dengan penerapan model SQ3R (Survey, Question, Read, Recite, Review) dengan media audio visual yang benar sesuai teori yang ada, peningkatan rata-rata prestasi belajar siswa pada siklus I dapat diupayakan dan mencapai rata-rata 74,70. Namun rata-rata tersebut belum maksimal karena hanya 21 siswa memperoleh nilai di atas 
KKM sedangkan yang lainnya belum mencapai KKM. Sedangkan prosentase ketuntasan belajar mereka baru mencapai $61,76 \%$. Hal tersebut terjadi akibat penggunaan model $S Q 3 R$ (Survey, Question, Read, Recite, Review) dengan media audio visual belum maksimal dapat dilakukan disebabkan penerapan model/metode tersebut baru dicobakan sehingga guru masih belum mampu melaksanakannya sesua alur teori yang benar.

Pada siklus ke II perbaikan prestasi belajar siswa diupayakan lebih maksimal dengan peneliti membuat perencanaan yang lebih baik, menggunakan alur dan teori dari model SQ3 $R$ (Survey, Question, Read, Recite, Review) dengan media audio visual dengan benar dan lebih maksimal. Peneliti giat memotivasi siswa agar giat belajar, memberi arahan-arahan, menuntun mereka untuk mampu menguasai materi pelajaran pada mata pelajaran Bahasa Indonesia lebih optimal. Akhirnya dengan semua upaya tersebut peneliti mampu meningkatkan prestasi belajar siswa pada siklus II menjadi rata-rata 81,61 dengan ketuntasan belajar mencapai $100 \%$. Upaya-upaya yang maksimal tersebut menuntun pada suatu keberhasilan bahwa penggunaan model pembelajaran SQ3R (Survey, Question, Read, Recite, Review) dengan media audio visual mampu meningkatkan prestasi belajar Bahasa Indonesia siswa kelas IX H semester II SMP Negeri 2 Blahbatuh tahun pelajaran 2018/2019.

Hasil penelitian ini sejalan dengan hasil penelitian yang dilakukan oleh Karmawan (2016) dengan judul Penerapan Metode Pembelajaran SQ3R Untuk Meningkatkan Keaktifan Dan Keterampilan Membaca Siswa Kelas IV SD. Hasil penelitian ini menunjukkan bahwa penerapan metode pembelajaran SQ3R dapat meningkatkan keaktifan dan keterampilan membaca pada siswa kelas IV semester II tahun pelajaran 2015/2016 di SDN 1 Kampung Baru. Hal ini dapat dilihat dari peningkatan keaktifan dan keterampilan membaca siswa dari siklus I sampai dengan siklus II. Pada siklus I persentase keaktifan belajar siswa sebesar $67,30 \%$ yang termasuk dalam (kategori cukup) dan persentase keaktifan belajar siswa pada siklus II sebesar $81,04 \%$ yang termasuk dalam (kategori baik). Sedangkan persentase keterampilan membaca siswa pada siklus I sebesar $66,09 \%$ yang termasuk dalam (kategori cukup) dan persentase keterampilan membaca siswa pada siklus II sebesar $80 \%$ yang termasuk dalam (kategori baik).

Penelitian yang dilakukan oleh Rahmawati (2016) dengan judul Penerapan SQ3R Berbantunan Reka Cerita Gambar Untuk Meningkatkan Pemahaman Membaca dan Hasil Belajar Siswa. Berdasarkan hasil observasi dan penelitian maka dapat disimpulkan bahwa penerapan model SQ3R (Survey Questions Reading Recite Review) berbantuan Reka Cerita Gambar dapat meningkatkan hasil belajar dan pemahaman membaca siswa kelas 4 SDN1 Bojong. Hasil belajar siswa mengalami penigkatan pada setiap siklus, pada siklus 1 siswa yang memiliki nilai tuntas atau $\geq 75$ sebanyak $63 \%$ dan siklus 2 siswa yang memiliki nilai tuntas atau $\geq 75$ sebanyak $78 \%$ dari siswa kelas 4 yang berjumlah 27 .

Penelitian yang dilakukan oleh Fitri (2011) dengan judul Penerapan SQ3R untuk meningkatkan kemampuan membaca pemahaman siswa kelas $\mathrm{V}$ di SDN Ketawanggede 2 Malang. Kesimpulan yang diperoleh dari penelitian ini: (1) penerapan SQ3R dapat meningkatkan kemampuan membaca pemahaman siswa kelas $\mathrm{V}$ yaitu memudahkan pemahaman siswa membaca isi bacaan, perbendaharaan kosa kata bahasa Indonesia siswa bertambah, lebih terampil merangkai kata dalam kalimat, mampu mengerjakan evaluasi dengan benar, menjawab pertanyaan guru dan mampu menceritakan kembali isi bacaan, (2) telah terjadi peningkatan kemampuan membaca pemahaman siswa kelas V SDN Ketawanggede 2 Malang yang ditunjukkan dari kualifikasi siklus I yaitu 7 siswa mendapatkan kriteria sangat baik, 13 siswa mendapatkan kriteria baik, 6 siswa mendapatkan kriteria cukup dan pada siklus II meningkat menjadi $53,8 \%$ siswa mendapatkan kriteria sangat baik dan $46,2 \%$ siswa mendapatkan kriteria baik.

\section{Simpulan}

Berdasarkan penelitian yang telah dilakukan dapat disimpulkan bahwa penerapan model pembelajaran SQ3R (Survey, Question, Read, Recite, Review) dengan media audio 
visual mampu meningkatkan prestasi belajar Bahasa Indonesia siswa kelas IX H semester II SMP Negeri 2 Blahbatuh tahun pelajaran 2018/2019.

\section{Daftar Pustaka}

Agung, A. A. Gede. 2011. Metodelogi Penelitian Pendidikan. Singaraja: Fakultas Ilmu Pendidikan Universitas Pendidikan Ganesha.

Agung, A. A. Gede. 2014. Metodologi Penelitian Pendidikan. Singaraja: Undiksha.

Anastasi, Anne. 1976. Psychological Testing. Fifth Edition.New York: Macmillan Publishing Co., Inc.

Arends, Richard I. 2004. Learning to Teach. Sixth Edition. New York: McGraw-Hill.

Asikin dan Pujiadi. Lembaran IImu Kependidikan Jilid 37, NO. 1, Juni 2008. Pengaruh Model Pembelajaran Bahasa Indonesia SQ3R (Survey, Question, Read, Recite, Review) Berbantuan Cd Interaktif Terhadap Kemampuan Pemecahan Masalah Pada Siswa Kelas X SMA Negeri 1 Semarang. FMIPA Unnes.

Aunurrahman. 2009. Belajar dan Pembelajaran. Bandung: Alfabeta.

Buchori, 2012. Artikel Hasil Penelitian. Pengaruh Model Pembelajaran Bahasa Indonesia SQ3R (Survey, Question, Read, Recite, Review) Berbantuan Software GeogebraTerhadap Kemampuan Pemecahan Masalah Pada Siswa SMA. Fakultas Pendidikan Bahasa Indonesia Dan IImu Pengetahuan Alam. IKIP PGRI Semarang.

Fitri, Setyorini. 2011. Penerapan SQ3R untuk meningkatkan kemampuan membaca pemahaman siswa kelas V di SDN Ketawanggede 2 Malang. Skripsi. Program Studi S1 PGSD Universitas Negeri Malang.

Karmawan, Gede Yogi. 2016. Penerapan Metode Pembelajaran SQ3R Untuk Meningkatkan Keaktifan Dan Keterampilan Membaca Siswa Kelas IV SD. Jurnal Mimbar IImu PGSD Undiksha Volume 4 Nomor 1.

Rahman, B. 2009. Skripsi.Perbandingan Kemampuan Koneksi Matematik Siswa yang Pembelajarannya Menggunakan Model SQ3R (Survey, Question, Read, Recite, Review) dengan Siswa yang Pembelajarannya Menggunakan Model Konvensional. FPMIPA UPI. Bandung.

Rahmawati, Aulia. 2016. Penerapan SQ3R Berbantunan Reka Cerita Gambar Untuk Meningkatkan Pemahaman Membaca dan Hasil Belajar Siswa. Jurnal Profesi Pendidikan Dasar, Vol. 3, No. 2.

Sanjaya, W. 2006. Strategi Pembelajaran. Jakarta: Kencana Prenada Media Group. 